
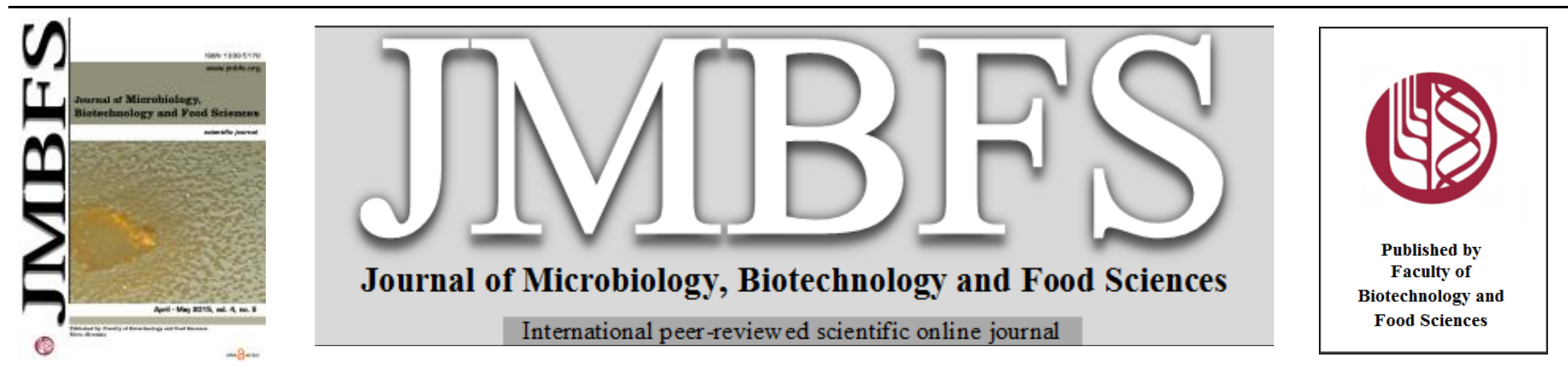

\title{
A REVIEW ON BIODEGRADABLE STARCH BASED FILM
}

\section{Hooman Molavi $^{*}{ }^{1}$, Somayyeh Behfar ${ }^{2,}$ Mohammad Ali Shariati $*^{3}$, Mehdi Kaviani $^{4}$,Shirin Atarod ${ }^{2}$}

\author{
Address(es): \\ ${ }^{1}$ Department of Food Science \& Technology, Sahrekord Branch, Islamic Azad University, Shahrekord, Iran. \\ ${ }^{2}$ Department of Food science and Technology, Tabriz Branch, Islamic Azad Univeristy, Tabriz, Iran. \\ ${ }^{3}$ Department of Food science and Technology, Science and Research Branch, Islamic Azad University, Tehran, Iran. \\ ${ }^{4}$ Department of Food science and Technology ,Derdowsi University of Mashhad ,Mashahd ,Iran.
}

*Corresponding author: hmolavi2010@yahoo.com

doi: $10.15414 / j m b f s .2015 .4 .5 .456-461$

\section{ARTICLE INFO}

Received 7. 1. 2015

Revised 12. 2. 2015

Accepted 10. 3. 2015

Published 1. 4. 2015

$\overline{\text { Review }}$

\begin{abstract}
In recent years, biodegradable edible films have become very important in research related to food, due to their compatibility with the environment and their use in the food packaging industry. Various sources can be used in the production of biopolymers as biodegradable films that include polysaccharides, proteins and lipids. Among the various polysaccharides, starch due to its low price and its abundance in nature is of significant importance. Several factors affect the properties of starch films; such as the source which starch is obtained from, as well as the ratio of constituents of the starch. Starch films have advantages such as low thickness, flexibility and transparency though; there are some downsides to mention, such as the poor mechanical properties and water vapor permeability. Thus, using starch alone to produce the film will led to restrictions on its use. To improve the mechanical properties of starch films and also increases resistance against humidity, several methods can be used; including the starch modifying techniques such as cross linking of starch and combining starch with other natural polymers. Other methods such as the use of lipid in formulations of films to increase the resistance to moisture are possible, but lipids are susceptible to oxidation. Therefore, new approaches are based on the integration of different biopolymers in food packaging.
\end{abstract}

Keywords: Biodegradable films, biopolymers, starch

\section{INTRODUCTION}

The tendency to use natural and renewable polymers in various fields is growing so that they can replace synthetic packaging films. In this regard, the starch concept is well known as a green material. This material is biodegradable, edible, and is not dependent on fossil resources while it is extensively available. Due to the growing demand for biodegradable materials it is expected to produce these materials in greater volume, so that starch is used in plastic films, laminates and natural composite fibers and can replace plastic foams. Starch-based films exhibit excellent physical properties and have no smell, no taste, and no color and are impermeable to oxygen. However there are some characteristics which can directly restrict its application such as; Strong hydrophilic properties (sensitivity to water) and poor mechanical properties compared to conventional synthetic polymers (Averous and Boquillon, 2004). This article discusses the starch-based films and latest suggested solutions proposed to overcome the disadvantages of biodegradable starch films while maintaining the desirable properties of these films.

\section{DIFFERENCES IN STARCH FILMS BASED ON THEIR SOURCE}

Depending on the starch source level, amylose and amylopectin can vary. Amylose is a linear chain of glucose having alpha-1, 4 glycosidic bonds and predominantly helical structure. While amylopectin is a branched polymer with higher molecular weight than amylose and these differences lead to differences in their molecular combination properties. Different forms of thermoplastic starch based on cassava indicate that existence of sugar and different molecular combinations interestingly correlate with the crystalline properties, water absorption and mechanical behavior. However, another study showed no significant difference between the triple kinetic values of starch, which represents a small effect on the thermal decomposition process of starch originated from various plant sources (Guinesi et al, 2006). Starch is not a true thermoplastic, though can melt and flow at the presence of softeners at high temperatures under the shear force. Research has showed that starch has good film forming properties; starch source plays a decisive role in the film features due to ratio of amylose to amylopectin and the different structural properties of macromolecules. Recent research is searching for alternative sources of starch that show a better performance and better physicochemical properties. One of the important starch sources is cassava which is produced in Latin America while its importance as a source of starch is increasingly on the rise, mainly due to low prices in the world market compared to other sources of starch.A study was conducted on cassava, checking the effect of temperature and storage time on its film. Results showed that no adverse changes were occurred in the film during 8 weeks of storage at room temperature.

Garcia et al. (2006) examined and compared the physicochemical properties of the starch films resulting from cassava and waxy maize, softened by glycerol. The researchers found that although both types of starch films are predominantly amorphous; in addition to the crystalline state (crystalline) Type B, waxy maize starch films also show Type A crystalline. In glandular starch, higher distribution of amorphous structure (amorphous) has been confirmed by FTIR; while areas with higher crystallinity (clusters of amylopectin) are observed in the starch grains micrographs. Cassava starch shows a greater interaction with glycerol indicating more hydrogen bonds with molecules of amylose than amylopectin chains. This observation has been confirmed by heating impact on thermal analysis (TGA) of cassava starch films compared with waxy maize and dynamic mechanical analysis (DMA) by position break peaks. These different reactions cause temperature increasing at the beginning of temperature decomposition of softened film of waxy maize. Rigidity of softened waxy maze film is higher in rubber state, compared to waxy maize starch. They also reported that the behavior is the same in both films, when exposed to moisture with a slight difference in the less permeability of starch films that is associated with the presence of amylopectin chains.

The Andean mountain ecosystem has the different potential sources of starch which can be used as raw materials to produce biodegradable polymers. Torres et al. (2011) displayed in a research study in which starch was extracted from 12 varieties from the anode region products. In this study, the film properties such as Young's modulus, ultimate tensile strength and elongation at rupture rate was investigated and it was showed that the properties of the starch depends on source used. Mechanical tests showed that the degradation of mechanical 
properties is lost. Weight loss rate in compost test of all starch films was more than the cellulose films (As a control). The biodegradation process consisted of three stages where the films were determined based on their rate of weight loss using FTIR analysis indicated that the first phase is associated with the leakage of glycerol. In this study, films produced from cassava and yam had the highest values of elongation at rupture rates. Most of Young's modulus of the films derived from sweet potato starch and the lowest potion derived from starch white carrot. Therefore, the mechanical properties of the films depend on the type of starch used in preparing the film. Films made from banana starch are more fragile than other films. Cassava and sweet potato films are both tough and rigid. In biodegradable point of view the highest percentage of weight loss was observed in cassava starch films, whereas the lowest was in the Golden Potato films. One of the best sources of starch up to $80 \%$ is Quinoa seed. This seed is found in very small dimensions (diameter $3 \mathrm{~mm}$ ) in high Andean regions of South America, which starches contain about 10 to 21 percent of amylose(depending on variety) Its granule size is small (about $1 \mathrm{~mm}$ ) and its features allow it to spread easily in solution therefore making the film suitable for the production (Ahamed $\boldsymbol{e t}$ al., 1996). Quinoa starch is efficient for the production of transparent biodegradable starch films which there is no need for chemical treatment. In a study by ArajvFarro et al. (2010) the optimal conditions for the production of Quinoa transparent edible films in molding process is $2 / 21 \%$ of glycerol, alkaline $\mathrm{pH}$ of $7 / 10$ and the drying temperature of $36^{\circ} \mathrm{C}$ for 14 hours. All the starch films produced in this study were colorless, transparent and flexible and could be easily applied while their surface was smooth and slick without the need for protection. Many researches were done on starch films obtained from high amylose maize and cassava, but there has been little research about the films made of sago starch (Nafchi $\boldsymbol{e t}$ al,2011). Sago starch has its own unique properties, but some of its physicochemical properties, are quite similar to the usual starch such as potatoes and cassava starch (Tie et al., 2008). In a research by Nafchi $\boldsymbol{e t}$ al. (2011) it was showed that films of sago starch, softened by sorbitol, perform better sealing properties than glycerol; although sago films show a less sealing strength than synthetic polymers but is the same as Carrageenan, casein - lactic acid and lipid isolated proteins emulsion films. The main limitation of starch-based biodegradable films is their hydrophilic character that leads to reduction of their stability when they are exposed to different environmental conditions (Forssell $\boldsymbol{e}$ al., 1999). Oat starch films are an interesting alternative because it contains about 1 to 3 percent fat in its natural structure, which is a considerable amount of starch in comparison with other sources (Wang et al., 1994). Steading and Peterson (Petersson and Stading, 2005) have investigated the use of lipids in reducing the hydrophilic properties of starch films; however, phase separation due to the incompatibility of the components occurred. Since lipids and amylose are naturally bonded in oat starch, the phase separation is prevented and thus contribute to reducing the hydrophilic properties of the substance (Galdeano $\boldsymbol{e t}$ al., 2009). Oat starch films softened by glycerol are functional and slick, yet have no cracks or bubbles in them. By increasing the relative humidity from 76 percen to 90 percent, no reduction in stress at any point of fracture has been occurred whereas Lawton (Lawton,2004) conversely implies this fact about zein films. This can be due to the protective role of lipids which prevent moisture absorption. But oat starch lipid is not adequate to prevent changes in mechanical properties caused by moisture (Galdeano et al., 2009). Considering the farming advantages of durum wheat, it has higher efficiency than normal wheat and is also more resistant to Karnal fungus (Datta et al., 1999).There are two types of granule in wheat starch; the large granules (Type A) and small granules (Type B) (Evers ,1973).Although durum wheat starch is not commercially available but has an interesting functional properties. Properties of films made from durum whea starch are highly affected by intrinsic feature of granules and concentration of softeners. Different granules of starch and other substances present in granule affect the mechanical properties of the films. Granule type of starch has great effects on the elongation of the film; granule type B shortens the length while type A lengthens it. Young's modulus of the films prepared with granules of type A (with the same amount of glycerol) was less than B granules (Montaño-Leyva et al., 2008). Some legume family of plants, such as Pachyrhizus Ahipa have are glandular roots which are rich in starch. This species naturally grow in smallscale in Andean regions of Bolivia and northern Argentina (López et al., 2010). Ahipa, is also easily adapted to different ecological conditions and as a promising alternative could be extended in various countries (López, O. and García ,2012) Few studies evaluating the insecticidal and antifungal properties of Ahipa was done. Some researchers have studied the similar species and stated that presence of a pesticide compound called "Rotnon" $(\mathrm{C} 23 \mathrm{H} 22 \mathrm{O} 6)$ is of the general characteristics of Pachyrhizus Ahipa. This compound is found in the ripe seeds while the roots of the raw plant are consumed by indigenous people in the Andean region (López and García, 2012).

Garcia and Lopez (2012) found the merits and superiority of Ahipa starch over maize starch. Benefits include lower amylose content (which is important in the Retro gradation discussion) and requiring less time and energy for gelatinization of suspension solutions. Overall, the researchers concluded that the use of nonregular starch (such as Ahipa) promote their production and also meets the needs for the development of food packaging materials with different functions.

\section{THE EFFECT OF STARCH COMPONENT ON FILM PROPERTIES}

Starch is a carbohydrate polymer of anhydrous glucose units which are connected together by alpha-1, 4 Glycoside bonds. Starch consists of amylose and amylopectin. Amylose is essentially linear structure of alpha-1, 4 bond that its behavior is more similar to synthetic polymers. In addition, its molecular weight is about 10, which is 106 times higher than conventional synthetic polymers. On the other hand, amylopectin has a highly branched structure with short chains linked to them through alpha-1, 4 bonds and alpha-1, 6 bonds. Molecular weight of amylopectin is about 108 that are much larger than amylose. High molecular weight and branched structure of amylopectin chain cause reduction in mobility of the polymer chains and undermines their tension to align and form hydro genic bonds significantly. In addition, the majority of starches are semi-crystalline and are of about 15 to $45 \%$ crystallinity (Zobel, 1988).Small branched chains of amylopectin are the most important crystal components in the granule (Veregin et al., 1986). Starches with different ratio of amylose to amylopectin deliver different behavior when the phase shifts (Liu et al., 2006) while showing various rheological properties during film production process such as extrusion(Chen et al., 2007). Films and sheets based on starch with high amylose content exhibit better mechanical performance (Van Soest and Borger, 1997). Amylose is capable of forming a stronger film than amylopectin; on the other hand amylopectin forms a light thin brittle film due to high degree of entanglement of the branches and shorter chain length (Thuwall et al., 2006; Rindlav-Westling et al., 1998; De Graaf et al., 2003; Lourdin et al., 1995). The conventional starch films which typically contain $75 \%$ amylopectin and 25 percent amylose are usually the most susceptible to this flaw. Their tensile strength is relatively high, which depends on the experimental conditions, but their elongation rate is low (Bader and Göritz, 1994). With the addition of a lubricant (such as glycerol) or with increasing moisture content, the glass transition temperature can be reduced and causes the molecules to get flexible and films may become weaker and elastic(Thunwall et al 2008; Mali et al,2006). In a study on low and high amylose containing starch films done by Muscot et al. (2012), it was showed that starch containing high amylose require a temperature higher than about $30^{\circ} \mathrm{C}$ gelatinization. Also, when the lubricant concentration in the film increases, the tensile strength and modulus of elasticity decreases; while the rate of elongation at rupture point in the films of both types of starch (high and low amylose containing) increases. In terms of flow behavior, low amylose starch suspensions show non-Newtonian Herschel Balckley, while high amylose starch suspensions show Herschel Balckley fluid behavior or Bingham plastic behavior.The results of $\mathbf{L i}$ et al. (2011) researches showed that, by increasing the amylose content of films the ability to process decreases, and with increasing water content, temperature, spiral speed and decreasing the amount of material entering the spiral, this ability is weakened. More temperature and moisture are essential for amylose process because of higher gelatinization temperature and long linear amylose chains tend to conflict with each other. Under some extrusion conditions, amylose content influences the microstructure and mechanical and thermal properties of starch films. For example, high-amylose starch films showed better mechanical properties such as high modulus, high tensile strength and much higher impact strength. Analysis of temperature and enthalpy of highamylose starch films showed a higher amount and by increasing amylose content, $\mathrm{Tg}$ of the films studied increased.In a study by Koch et al. (2011) on the mechanical properties and structural properties of high-amylose starch films, the results showed a high molecular weighted amylopectin and amylose tend to break down during that process. However, this analysis which affect the of micro and macro structure, have no similar impact on mechanical properties; as no significant effect on processing time and heating temperature on the mechanical properties was observed. This is probably because when the processing time increases, it allows starch to leak from granules and increase the final molecular concentration of films.

\section{MODIFIED STARCH BASED FILM}

Although functional, mechanical and organoleptic properties of starch based films can be modified by the addition of various chemicals in certain quantities (Mali et al., 2004), since starch films are edible, the chemicals are not suitable. Consumers prefer modified starch based films, this way starch modifiers have been developed. Starch modified by oxidation or thermal process under moisture treatment is considered the most functional option for the production of films (Zavareze et al., 2012). Modifying starch can be an efficient instrument to adjust the general properties of starch films especially for the production of coating materials that are less sensitive to water (Lafargue $\boldsymbol{e t}$ al., 2007; López $\boldsymbol{e t}$ al., 2008). The potato starch based films have higher tensile strength and lower elongation rate of condensation at the point of rupture, solubility and permeability to water vapor, than normal starch based films. Heat-moisture treatment of potato starch films, increase the tensile strength and their permeability to water vapor, much more than normal starch films. These results indicate that modified potato starch based film can produce films with different properties which are functional depending on different applications(Zavareze $\boldsymbol{e t}$ al., 2012). A common approach to improve the performance of starch for various applications is cross-linking of starch. Starch and starch products are cross-linked 
with cross-linking material such as phosphor oxy chloride, sodium tri Meta phosphate, epichlorohydrine, 1,2,3,4 di epoxibutal, to improve mechanical properties and stability of aqueous starch products (Kunaik et al., 1972; Seker and Hanna 2006; Simkovic et al., 2004; Wattanachant et al., 2003).Polycarboxylic acids such as citric acid are inexpensive and non-toxic chemicals that have been used to improve the performance properties of cellulose and protein in textile industry (Yang et al., 1991). Acid citric can link with starch through hydrogen bond which can help maintain and improve its thermal and water stability to prevent it from retro degradation (Yu et al., 2005). In a study by Reddy and Yang (2010) it was showed that crosslinking of starch by citric acid can improve its mechanical properties. Citric acid reclaims the starch films strength and significantly reduces weight loss of films in formic acid and water This type of starch is 150 percent stronger than non-modified starch films, and Most of the cross-linked films as well as starch films mixed with synthetic polymers show better strength. Thermal stability of these films in the temperature range of 320 to $600^{\circ} \mathrm{C}$ is more than non-modified starch films. Cross linking through citric acid decreases water vapor penetration and color of the film but results in no significant alteration in film morphology and crystallinity rate. In a study by Lopez et al. (2010) film forming capability of chemically modified maize starch addressed. In this study, it was indicated that modified starch by acid is not able to create a continuous network film, however has the same amount of amylose as normal starch. Amylose is in charge of film formation in starch molecules (5). Acid treatment can lead to hydrolysis of the polymer chains and reduces the average molecular weight of linear chains, which is the reason why its suspension shows Newtonian behavior. Acetylated starch in this study established the best properties for film formation and transparent film production while it was easily detached from the plate .Another chemically modified starch film is hydroxypropyled starch. Hydroxyl propyl groups are hydrophilic compounds affecting interaction between starch molecules. A direct comparison was done among hydroxypropyled starch of peas, potato and maize and resulted in no considerable difference in tensile strength and elongation rate of any type (Vorwerg $\boldsymbol{e t}$ al., 2004).Oxidized starch is used in many different industries to provide properties such as coverage and reduction in the permeability of the surface. Although most of the oxidized starch is used in textile and paper industries, their application in the food industry is highly rising due to its low viscosity, high stability, film forming properties and linking character (Kuakpetoon and Wang, 2001). Hu et al. (2009) expressed that due to its high molecular weight, potato starch has a higher tensile strength, allowing its paste to gain higher viscosity. Therefore, the preparation of potato starch paste with high starch concentration led to a decrease in film production efficiency. In addition, natural potato starch paste clarity is less than oxidized potato starch. The natural ones are transparent, flexible and slick while the oxidized ones are brittle and prone to be cracked. Oxidized ones are impermeable to oil and stable in acidic solutions; thus can be used for packaging oily, non-alkaline materials. This film tends to re-crystallization at normal temperature and humidity conditions; therefor has suitable shelf-stable packaging character as a packaged material.The tensile strength of the oxidized banana starch films increases with increasing oxidation level, with no significant difference in retaining of this property up to 60 days. In this time period no significant differences in permeability to water vapor was observed (Zamudio-Flores et al., 2006).

\section{IMPROVEMENT OF STARCH FILMS PROPERTIES USING OTHER NATURAL POLYMERS}

To improve the properties of starch films, natural fibers can be used as an amplifier that is suitable for thermoplastic materials. Many studies have been done on the mechanical properties of the films, showing that the addition of fibers increases the tensile strength and elastic modulus of the films and reduce their degree of elongation (Ave' rous et al., 2001; Curvelo et al., 2001; Ma and Kennedy 2005). Mixing Cellulose fibers mechanically strengthens starch films and increases tensile strength and reduces the possibility of deformation. Compared to reinforced films, starch films are less permeable than water vapor. Since cellulose fibers are biodegradable and low cost, they are available, and their application as an alternative amplifier to improve the properties of starchbased films has increased (Muller et al., 2009 ; Dufresne $\boldsymbol{e t}$ al., 2007). When natural fibers are mixed with starch due to the chemical similarity of starch with plant fibers, interactions and reactions occur that cause evident and clear improvement in the compound (Lu et al., 2006).Carboxymethyl cellulose had no detrimental effects on human health, and has been widely applied as additives in various fields such as food industry, healthcare, pharmaceutical industries, textile and pharmaceutical applications (Ma et al., 2008). Addition of carboxymethyl cellulose improves the moisture resistance of the composites. With the addition of $15 \%$ carboxy methyl cellulose, water vapor permeability, moisture absorption and solubility of films decrease (Ghanbarzadeh $\boldsymbol{e t}$ al., 2011).Carboxy methyl cellulose cause enhancement of amorphous structure, in maize starch network, however micrographs of electronic microscope show the polymer phase separation causing the film to lose its smoothness. Compared to pure starch films and hydroxyl cellulose, elastic modulus of fresh composite film is declined; though tensile strength and deformation at rupture point is improved slightly. Composite films show a great permeability to oxygen and similar permeability to water vapor as other types (Jiménez et al., 2012). Bio-nanocomposites are functional compounds which have been studied recently in order to improve food packaging industry. Cellulose nano-crystals are used to improve starch (Kvien et al., 2007) when a natural cellulose is exposed to strong acidic hydrolysis, turns into nano crystal( Bondeson et al., 2006; Zhang et al., 2007) The most common method for producing cellulose nano-composites is molding aqueous solutions or other solvents (Petersson et al., 2007; Kvien and Oksman, 2007). Savadkar and Mask (Savadekar and Mhaske, 2012) provided nano composites and mixed them with starch and produced a film with high tensile strength and low vapor and oxygen flow. Nano crystals are useful to boost butyrate acetate (Roman and Winter, 2002) and carboxyl methyl cellulose (Choi and Simonsen, 2006) cellulose bio-composites, and even synthetic polymers such as PVC (Chazeau $\boldsymbol{e t}$ al., 2000) and poly oxy ethylene (Samir $\boldsymbol{e t}$ al,2004).

Research has showed that a combination of starch and chitosan improves functional properties of each of them alone (Bourtoom and Chinnan, 2008; Vásconez et al., 2009; Xu et al., 2005). Chitosan is made by chitin en-di acetylation which is the second abundant polysaccharide in nature. Chitosan films are potentially efficient for edible films. These films are usually made by solvent evaporation, chemical crosslinking or mixing with other substances such as proteins. However, mechanical properties and permeability of these films make them suitable; they need to be reformed for specific applications (Begin $\boldsymbol{e}$ al., 1999; Mathew et al., 2008; Ham-Pichavant et al., 2005). Chitosan does not directly dissolve in water and exclusively dissolves in some acidic solutions such as acetic acid, citric acid, ascorbic acid, formic acid, lactic acid, malic acid, Oxalic acid, succinic acid, propionic acid and adipine acid (Chen et al., 2008; Kim et al., 2006). Due to the interaction between chitosan and various acids, solution properties of chitosan and chitosan films are influenced by the properties of acids including hydrodynamic volume of chitosan molecules in solution, relative permeability to water vapor, oxygen permeability and mechanical properties of chitosan films (Kim et al., 2006; Chen et al., 2009; Park et al., 2002 ).Chitosan-starch films have successfully exhibited films with good antimicrobial activity against Escherichia coli and Staphylococcus aureus. These film making components have good compatibility and data obtained from FTIR and XRD confirms it. Various acids that are used as solvents altered the molecular interactions between the components and eventually affected the final properties of the film. These composite films made by malic acid solution, can be a greater barrier against moisture and low water absorption, due to crystallization of malic acid in ambient temperature. In terms of mechanical properties, acetic acid film is stronger than the other two, while it has the lowest solubility. Acetic acid film makes more transparent films.Lactic acid films present a better flexible film; therefor, by choosing different acids to dissolve chitosan, various films are produced with different properties, according to different demands (Zhong $\boldsymbol{e t}$ al., 2011). Plisary et al. (2012) also stated that the addition of small amounts of chitosan to starch films resulted in increment in mechanical strength and reduction in permeability to moisture ratio.Another way to increase the solubility of chitosan in neutral or alkaline solutions is entering the carboxymethyl groups in some amino sites and primary hydroxyl site in glucosamine units of the chitosan structure (Jayakumar et al., 2010). FTIR studies indicate that Nano crystalized starch form hydrogen bonds with carboxymethyl chitosan. In these types of films water absorption and water vapor permeability has improved (Duan et al., 2011). In another study by Tuhin $\boldsymbol{e t}$ al. (2012) on the thermal and mechanical properties of modified chitosan-starch films, it was showed that the modified gamma ray film shows enhanced thermal and water stability of the films. Garcia et al. (2006) indicated that starch-chitosan suspensions express sod plastic behavior just like chitosan suspensions. These films are resistant and their flexibility is enhanced with increment of glycerol.In general, starch-chitosan films are considered as biofilms with homogeneous network, sustainable building and interesting properties such as protection against moisture and mechanical properties, providing the opportunity of high use and advantages of biodegradation (Garcia et al., 2006). Sodium casein capability to form films with desired properties is well known (Audic and Chaufer 2005; Fabra et al., 2010). Several reports were released based on the healing properties of polymer films with addition of sodium casein. Monedero et al. (2010) examined the healing effect of sodium and potassium salts on the properties of casein films prepared from soy protein isolates and found out that the addition of casein (especially calcium casein) increases the elastic modulus and tensile strength of the film at the rupture point.Pereda et al. (2011) studied the properties of films prepared from sodium casein and cellulose derivatives (carboxymethyl cellulose and cellulose acetate). Jiménez et al. (2012) stated that the addition of casein to corn starch reduces the degree of crystallinity of starch films and prevents starch recrystallization during storage. The composition of hydrocolloids and starch alters the properties of starch films, for example they can restrict the retro degradation pace (Yoshimura et al., 1999). The composition of Xanthan gum and cassava starch cause delaying in the process leading to crystallization; though has no impact on kinetic and mechanical properties of water absorption of films compared to control (Santos et al., 2005). Addition of xanthan to a solution containing $5 \%$ of pea starch, can produce a firm film; causing no interference in physical and mechanical properties of films (Matta et al., 2011). In another research, it was concluded that the use of deacethylated xanthan gum lead to 
significant effects on the mechanical property kinetics and water absorption, whereas no enormous influence was observed on the final product compared with control subjects (Veiga-Santos $\boldsymbol{e t}$ al., 2005).One of the natural water-soluble polysaccharides available in the roots and tubers of the plant Amorphophallus konjac is konjac glucomannan which is widely applied in processed food and biomedical substances (Chen et al., 2005). Nair et al. (2011) prepared and optimized a film using cassava starch, konjac glucomannan and glycerol. The film showed less crystallinity, better mechanical properties and lower water vapor transmission rates and solubility compared to pure starch film. These studies have proved that functional synergic interactions between starch and konjac glucomannan improves physical properties of the film making it useful for applications such as edible films, coating and drugs requiring controlled release.Application of filling compounds in composite films was also addressed According to this study, mixture of natural fillers (creatine, lignin and cellulose) with starch network, improves the chemical and physical properties of starch based films protecting their advantaged meanwhile. These films are resistant yet have higher tensile strength. The creatine component of starch-based films increases the thermal stability; simultaneously, the film achieves greate hydrophobicity and less moisture absorption in the atmosphere with high humidity. With the addition of filler to the films, transparency is declined due to the presence of lignin (Bodirlau et al., 2013).

\section{CONCLUSION}

According to the recent researches on the application of biodegradable biofilms in food packaging industry, it has been said that starch is an important and promising source. Demands on the different application of biofilms in food packaging industry have made researchers to investigate various sources of starch because of the specific characteristics of each. To accommodate the starch to produce the desired film, it can be modified by using different materials while this action aims to produce films with desirable properties, free of any harmful chemicals.Another approach to modify mechanical properties and permeability of starch is to use other polymers in starch-based films to improve antimicrobia impact. Recent studies were done on the combination starch films, using Bionano-composite that can leave a better effect on the properties of these films

\section{REFERENCES}

AHAMED, T. N., SNGHAL, R. S., KULKARNI, P. R., KALE, D. D. and Pal, M. 1996. Studies on Chenopodium quinoa and Amaranthus paniculatas starch as biodegradable fillers in LDPE films. Carbohydrate Polymers, 31, 157-160. http://dx.doi.org/10.1016/s0144-8617(96)00019-7.

ARAUJO-FARRO, P. C., PODADERA, G., SOBRAL, P. J. A. and MENEGALLI, F. C. 2010. Development of films based on quinoa (Chenopodium quinoa, Willdenow) starch. Carbohydrate Polymers, 81, 839-848. http://dx.doi.org/10.1016/j.carbpol.2010.03.051.

AUDIC, J. L. and CHAUFER, B. 2005. Influence of plasticizers and crosslinking on the properties of biodegradable films made from sodium caseinate. European Polymer Journal, 41(8), 1934-1942.

AVEROUS, L., FRINGANT, C. and MORO, L. 2001. Plasticized starchcellulose interactions in polysaccharides composites. Polymer, 42, 6565-6572. http://dx.doi.org/10.1016/s0032-3861(01)00125-2

AVEROUS, L. and BOQUILLON, N. 2004. Biocomposites based on plasticized starch: thermal and mechanical behaviours. Carbohydrate Polymers, 56, 111 122. http://dx.doi.org/10.1016/j.carbpol.2003.11.015.

BADER, H. and GORITZ, D. 1994. Investigations on High Amylose Corn Starch Films. Part 3: Stress Strain Behaviour. Starch - Stärke, 46(11), 435-439. http://dx.doi.org/10.1002/star.19940461106.

BEGIN, A. and CALSTEREN, M. V. 1999. Antimicrobial films produced from chitosan. International Journal of Biological Macromolecules, 26, 63-67. http://dx.doi.org/10.1016/s0141-8130(99)00064-1.

BODIRLAU, R., TEACA, C. A. and SPIRIDON, I. 2013.Influence of natural fillers on the properties of starch-based biocomposite films. Composites: Part B, 44(1), 575-583. http://dx.doi.org/10.1016/j.compositesb.2012.02.039

BONDESON, D., MATHEW, A. and OKSMAN, K. 2006. Optimization of the isolation of nanocrystals from microcrystalline cellulose by acid hydrolysis. Cellulose, 13(2): 171-180. http://dx.doi.org/10.1007/s10570-006-9061-4.

BOURTOOM, T. and CHINNAN, M. S. 2008. Preparation and properties of rice starch-chitosan blend biodegradable film. LWT, 41(9), 1633-1641. http://dx.doi.org/10.1016/j.1wt.2007.10.014.

CHAZEAU, L., CAVAILle, J. Y. and PEREZ, J. 2000. Plasticized PVC reinforced with cellulose whiskers II. Plastic behavior. Journal of Polymer Science: Part B: Polymer Physics, 38(3), 383-392. http://dx.doi.org/10.1002/(sici)1099-0488(20000201)38:3<383::aidpolb5>3.3.co;2-h

CHEN, L. G., LIU, Z. L. and ZHUO, R. X. 2005. Synthesis and properties of degradable hydrogels of konjac glucomannan grafted acrylic acid for colonspecific drug delivery. Polymer, 46, 6274-6291. http://dx.doi.org/10.1016/j.polymer.2005.05.041.
CHEN, P., YU, L., KEALY, T., CHEN, L. and LI, L. 2007. Phase transition of starch granules observed by microscope under shearless and shear conditions. Carbohydrate, 68(3), 495-501. http://dx.doi.org/10.1016/j.carbpol.2006.11.002. CHEN, P. H., KUO, T. Y., LIU, F. H., HWANG, Y. H., HO, M. H. WANG, D. M. and et al. 2008. Use of dicarboxylic acids to improve and diversify the material properties of porous chitosan membranes. Journal of Agricultural and Food Chemistry, 56(19), 9015-9021. http://dx.doi.org/10.1021/jf801081e.

CHEN, R. H., CHEN, W. Y., WANG, S. T., HSU, C. H. and TSAI, M. L. 2009 Changes in the Mark-Houwink hydrodynamic volume of chitosan molecules in solutions of different organic acids, at different temperatures and ionic strengths. Carbohydrate $\quad$ Polymers, 78(4), 902-907. http://dx.doi.org/10.1016/i.carbpol.2009.07.027

CHOI, Y. and SIMONSEN, J. 2006. Cellulose nanocrystal-filled carboxymethyl cellulose nanocomposites. Journal of Nanoscience and Nanotechnology, 6(3), 633-639. http://dx.doi.org/10.1166/jnn.2006.132.

CURVELO, A. A. S., DE CARVALHO, A. J. F. and AGNELli, J. A. M. 2001 Thermoplastic starch- Thermoplastic starchcellulosicfibers. Carbohydrate Polymers, 45, 183-188.

DATTA, R., HARJIT-SINGH, GUPTA, V. S., RANJEKAR, P. K. and DHALIWAL, H. S. 1999. Gene-for-gene relationship for resistance in wheat. Plant Breeding, 118, 362-364. http://dx.doi.org/10.1046/j.14390523.1999.00391.X

DE GRAAF, R. A., KARMAN, A. P. and JANSSEN, L. P. B. M. 2003. Material Properties and Glass Transition Temperatures of Different Thermoplastic Starches After Extrusion Processing. Starch - Stärke, 55(2), 80-86 http://dx.doi.org/10.1002/star.200390020

DUAN, B., SUN, P., WANG, X. and YANG, C. 2011. Preparation and properties of starch nanocrystals/carboxymethyl chitosan nanocomposite films. Starch Starke, 63,528-535. http://dx.doi.org/10.1002/star.201000136.

DUFRESNE, A., DUPEYRE, D. and VIGNON, M. R. 2000. Cellulose microfibrils from potato tuber cells: processing and characterization of starch cellulose microfibril composites. Journal of Applied Polymer Science, 76, 20802092. $\quad$ http://dx.doi.org/10.1002/(sici)1097-4628(20000628)76:14<2080::aidapp12>3.0.co;2-u

EVERS, A. D. 1973. The Size Distribution Among Starch Granules in Wheat

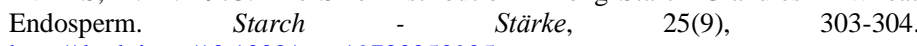
http://dx.doi.org/10.1002/star.19730250905.

FAMA', L., GOYANES, S. and GERSCHENSON, L. 2007. Influence of storage time at room temperature on the physicochemical properties of cassava starch films. Carbohydrate Polymers, 70, 265-273. http://dx.doi.org/10.1016/i.carbpol.2007.04.003.

FABRA, M. J., TALENS, P. and CHIRALTI, A. 2010. Influence of calcium on tensile, optical and water vapour permeability of sodium caseinate edible films. Journal of Food Engineering, 96(3), 356-364 http://dx.doi.org/10.1016/j.jfoodeng.2009.08.010.

FORSELL, P. M., MIKKILA, J. M., MOATES, G. K. and PARKER, R. 1997. Phase and glass transition behaviour of concentrated barley starch-glycerol-water mixtures, a model for thermoplastic starch. Carbohydrate Polymers, 34, 275-282. http://dx.doi.org/10.1016/s0144-8617(97)00133-1

FORSELL, P. M., HULLEMAN, S. H. D., MYLLARINEN, P. J., MOATES, G. K. and PARKER, R. 1999. Ageing of rubbery thermoplastic barley and oat starches. Carbohydrate Polymers, 39, 43-51. http://dx.doi.org/10.1016/s01448617(98)00128-3.

GALDEANO, M. C., GROSSMANN, M. V. E., MALI, S., BELLO-PEREZ, L. A., GARCIA, M. A. and ZAMUDIO-FLORES, P. B. 2009. Effects of production process and plasticizers on stability of films and sheets of oat starch. Materials

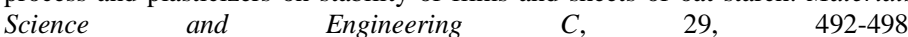
http://dx.doi.org/10.1016/j.msec.2008.08.031.

GARCIA, M. A., PINOTTI, A. and ZARITZKY, N. E. 2006. Physicochemical, Water Vapor Barrier and Mechanical Properties of Corn Starch and Chitosan Composite Films. Starch - Stärke, 58, 453-463. http://dx.doi.org/10.1002/star.200500484.

GARCIA, N. L., FAMA, L., DUFRESNE, A., ARANGUREN, M., GOYANES, S. 2009. A comparison between the physico-chemical properties of tuber and cereal starches. Food Research International, 42, 976-982. http://dx.doi.org/10.1016/j.foodres.2009.05.004.

GHANBARZADEH, B., ALMASI, H. and ENTEZAMI, A. A. 2011. Improving the barrier and mechanical properties of corn starch-based edible films: Effect of citric acid and carboxymethyl cellulose. Industrial Crops and Products, 33, 229235. http://dx.doi.org/10.1016/j.indcrop.2010.10.016.

GUINSENI, L. S., DA ROZ, A. L., CORRADINI, E., MATTOSO, L. H. C. TEIXEIRA, E. D. M. and CURVELLO, A. A. d. S. 2006. Kinetics of thermal degradation applied to starches from different botanical origins by nonisothermal procedures. Thermochimica Acta, 447, 190-196. http://dx.doi.org/10.1016/j.tca.2006.06.002 .

HAM-PICHAVANT, F., SEBE, G., PARDON, P. and COMA, V. 2005. Fa resistance properties of chitosan-based paper packaging. Carbohydrate Polymer 61, 259-265. http://dx.doi.org/10.1016/j.carbpol.2005.01.020. 
HU, G., CHEN, J. and GAO, J. 2009. Preparation and characteristics of oxidized potato starch films. Carbohydrate Polymers, 76, 291-298. http://dx.doi.org/10.1016/j.carbpol.2008.10.032

JAYAKUMAR, R., PRABAHARAN, M., PRABAHARAN, S. V., TOKURA, S., TAMURA, H. and SEWAMURUGANN. 2010. Novel carboxymethyl derivatives of chitin and chitosan materials and their biomedical applications. Progress in Materials Science, 55, 675-709. http://dx.doi.org/10.1016/j.pmatsci.2010.03.001.

JIMENEZ, A., FABRA, M. J., TALENS, P. and CHIRALT, A. 2012. Effect of sodium caseinate on properties and ageing behaviour of corn starch based films. Food Hydrocolloids,

http://dx.doi.org/10.1016/j.foodhyd.2012.03.014

JIMENEZ, A., FABRA, M. J., TALENS, P. and CHIRALIT, A. 2012. Influence of hydroxy propyl methyl cellulose addition and homogenization conditions on properties and ageing of corn starch based films. Carbohydrate Polymers, 89: 676-686. http://dx.doi.org/10.1016/j.carbpol.2012.03.075.

KVIEN, I. and OKSMAM, K. 2007. Orientation of cellulose nanowhiskers in polyvinyl alcohol. Applied Physics A: Materials Science and Processing, 87(4), 641-643. http://dx.doi.org/10.1007/s00339-007-3882-3 .

KVIEN, I., SUGIYAMA, J., VOTRUBEC, M. and OKSMANN, K. 2007. Characterization of starch based nanocomposites. Journal of Materials Science, 42(19), 8163-8171. http://dx.doi.org/10.1007/s10853-007-1699-2 .

KIM, K. M., SON, J. H., KIM, S. K., WELLER, C. L. and HANNA, M. A. 2006 Properties of chitosan films as a function of $\mathrm{pH}$ and solvent type. Journal of Food Science, $\quad 71(3), \quad$ E119-E124. http://dx.doi.org/10.1111/j.13652621.2006.tb15624.x.

KOCH, K., GILLGREN, T., STADING, M. and ANDERSONN, R. 2010 Mechanical and structural properties of solution-cast high-amylose maize starch films. International Journal of Biological Macromolecules, 46, 13-19. http://dx.doi.org/10.1016/j.ijbiomac.2009.10.002.

KUAKPETOON, D. and WANG, Y. Characterization of Different Starches Oxidized by Hypochlorite. Starch - Stärke, 53, 211-218 http://dx.doi.org/10.1002/1521-379x(200105)53:5<211::aid-star211>3.0.co;2-m KUNAIK, L. and MARCHSSAULT, R. H. 1972. Study of cross-linking reaction between epichlorohydrin and starch. Starch - Stärke, 24(4), 110-116. http://dx.doi.org/10.1002/star.19720240404.

LAFARGUE, D., LOURDIN, D. and DOUBLIER, J. L. 2007. Film-forming properties of a modified starch/k-carrageenan mixture in relation to it rheological behaviour. Carbohydrate Polymers, 70(1), 101-111. http://dx.doi.org/10.1016/j.carbpol.2007.03.019

LAWTON, J. W. 2004. Plasticizers for Zein: Their Effect on Tensile Properties and Water Absorption of Zein Films. Cereal Chemistry, 1, 1-5. http://dx.doi.org/10.1094/cchem.2004.81.1.1.

LI, M., LIU, P., ZOU, W., YU, L., XIE, F., PU, H., LIU, H. and CHEN, L. 2011. Extrusion processing and characterization of edible starch films with different amylose contents. Journal of Food Engineering, 106, 95-101. http://dx.doi.org/10.1016/j.jfoodeng.2011.04.021.

LIU, H. S., YU, L., XIE, F. W. and CHEN, L. 2006. Gelatinization of cornstarch with different amylose/amylopectin content. Carbohydrate Polymers, 65(3), 357 363. http://dx.doi.org/10.1016/j.carbpol.2006.01.026

LOPEZ, O. V., GARCIA, M. A. and ZARITZKY, N. E. 2008. Film forming capacity of chemically modified corn starches. Carbohydrate Polymers, 73, 573581. http://dx.doi.org/10.1016/j.carbpol.2007.12.023

LOPEZ, O. V., VNA, S. Z. PACHAS, A. N. A., SISTERNA, M. N., ROHATSCH, P. H., MUGRIDGE, A., FASSOLA, H. E., GARCIA, M. A. 2010 Composition and food properties of Pachyrhizus ahipa roots and starch International Journal of Food Science and Technology, 45(2), 223-233. http://dx.doi.org/10.1111/j.1365-2621.2009.02125.x.

LOPEZ, O. V., ZARITZKY, N. E. and GARCIA, M. A. 2010. Physicochemical characterization of chemically modified corn starches related to rheological behavior, retrogradation and film forming capacity. Journal of Food Engineering, 100, 160-168. http://dx.doi.org/10.1016/j.jfoodeng.2010.03.041

LOPEZ, O. V. and GARCIA, M. A. 2012. Starch films from a nove (Pachyrhizus ahipa) and conventional sources: Development and characterization. Materials Science and Engineering C, 32, 1931-1940. http://dx.doi.org/10.1016/j.msec.2012.05.035.

LOURDIN, D., VALLE, G. D. and COLLONA, P. 1995. Influence of amylose content on starch films and foams. Carbohydrate Polymers, 27(4), 261-270 http://dx.doi.org/10.1016/0144-8617(95)00071-2 .

LU, Y. S., WENG, L. H. and CAO, X. D. 2006. Morphological, thermal and mechanical properties of ramie crystallites-reinforced plasticized starch biocomposites. Carbohydrate Polymer, 63, 198-204. http://dx.doi.org/10.1016/j.carbpol.2005.08.027.

MA, X., YU, J. and KENNEDY, J. F. 2005. Studies on the properties of natural fibers reinforced themoplastics starch composites. Carbohydrate Polymers, 62, 19-24. http://dx.doi.org/10.1016/j.carbpol.2005.07.015

MA, X., CHANG, P. R. and YU, J. 2008. Properties of biodegradable thermoplastic pea starch/carboxymethyl cellulose and pea starch/microcrystalline cellulose composites. Carbohydrate Polymer, 72, 369-375 http://dx.doi.org/10.1016/j.carbpol.2007.09.002

MALI, S., GROSSMANN, M. V. E., GARCIA, M. A., MARTINO, M. N. and ZARITZKY, N. E. 2004. Barrier, mechanical and optical properties of plasticized yam starch films Carbohydrate Polymers, 56, 129-135. http://dx.doi.org/10.1016/j.carbpol.2004.01.004

MALI, S., GROSSMANN, M. V. E., GARCIA, M. A., MARTINO, M. N. and ZARITZKY, N. E. 2006. Effects of controlled storage on thermal, mechanical and barrier properties of plasticized films from different starch sources. Journal of Food Engineering, 75(4), 453-460. http://dx.doi.org/10.1016/j.jfoodeng.2005.04.031

MATHEW, S. and ABRAHAM, T. E. 2008. Characterisation of ferulic acid incorporated starch-chitosan blend films. Food Hydrocolloids, 22, 826-835. http://dx.doi.org/10.1016/j.foodhyd.2007.03.012

MATTA, M. D., SARMENTO, S. B., OLIVEIRA, L. M. and ZOCCHI, S. S. 2011. Mechanical properties of pea starch films associated with xanthan gum and glycerol. Starch - Starke, 63, 274-282. http://dx.doi.org/10.1002/star.201000088. MONEDERO, F. M., FABRA, F. M., TALENS, P. and CHIRALT, A. 2010. Effect of calcium and sodium caseinate son physical characteristics of soy protein isolate-lipid films. Journal of Food Engineering, 97(2), 228-234. http://dx.doi.org/10.1016/j.carbpol.2011.05.063.

MOTANO-LEYVA, B., TORRES-CHAVEZ, P., RAMIREZ-WONG, B., Plascencia-Jatomea, M. and Brown-Bojórquez, F. 2008. Physical and Mechanical Properties of Durum Wheat (Triticum durum) Starch Films Prepared with A- and B-type Granules. Starch - Stärke, 60, 559-567. http://dx.doi.org/10.1002/star.200800227.

MULLER, C. M. O., LAURINDO, J. B. and YAMASHITA, F. 2009. Effect of cellulose fibers addition on the mechanical properties and water vapor barrier of starch-based films. Food Hydrocolloids, 23, 1328-1333. http://dx.doi.org/10.1016/j.foodhyd.2008.09.002.

MUSCAT, D., ADHIKARI, B., AHIKARI, R. and CAUDHARY, D. S. 2012. Comparative study of film forming behaviour of low and high amylose starches using glycerol and xylitol as plasticizers. Journal of Food Engineering, 109, 189201. http://dx.doi.org/10.1016/j.jfoodeng.2011.10.019.

NAFCHI, A. M., CHENG, L. H. and KARIM, A. A. 2011. Effects of plasticizers on thermal properties and heat sealability of sago starch films. Food Hydrocolloids, 25, 56-60. http://dx.doi.org/10.1016/j.foodhyd.2010.05.005.

NAIR, S. B., JYOTHI, A. N., SAJEEV, M. S. and MIRSA, R. 2011. Rheological, mechanical and moisture sorption characteristics of cassava starch-konjac glucomannan blend films. Starch/Starke, 63, 728-739. http://dx.doi.org/10.1002/star.201100051.

PARK, S. Y., MARSH, K. S. and RHIM, J. W. 2002. Characteristics of different molecular weight chitosan films affected by the type of organic solvents. Journal of Food Science, 67(1), 2777-2784. http://dx.doi.org/10.1111/j.1365 2621.2002.tb11382.x

PELISSARI, F. M., YAMASHITA, F., GARCIA, M. A., MARTINO, M. N., ZARITZKY, N. E. and GROSSMANN, M. V. E. 2012. Constrained mixture design applied to the development of cassava starch-chitosan blown films. Journal of Food Engineering, 108, 262-267. http://dx.doi.org/10.1016/j.jfoodeng.2011.09.004 .

PEREDA, M., AMICA, G., RACZ, I. and MARCOVICH, N. E. 2011 Preparation and characterization of sodium caseinate films reinforced with cellulose derivates. Carbohydrate Polymers, 86(2), 1014-1021. http://dx.doi.org/10.1016/j.carbpol.2011.05.063.

PETERSONN, M. and STANDING, M. 2005. Water vapour permeability and mechanical properties of mixed starch-monoglyceride films and effect of film forming conditions. Food Hydrocolloids, 19, 123-132. http://dx.doi.org/10.1016/j.foodhyd.2004.04.021

PETERSSON, L., KVIEN, I. and OKSMAM, K. 2007. Structure and therma properties of poly(lactic acid)/cellulose whiskers nanocomposite materials Composites Science and Technology, 67(11-12), 2535-2544. http://dx.doi.org/10.1016/j.compscitech.2006.12.012.

REDDY, N. and YANG, Y. 2010. Citric acid cross-linking of starch films. Food Chemistry, 118, 702-711. http://dx.doi.org/10.1016/j.foodchem.2009.05.050.

RINDLAV-WESTLING, A., STADING, M., HERMANSSON, A. and GATENHOLM, P. 1998. Structure, mechanical and barrier properties of amylose and amylopectin films. Carbohydrate Polymers, 36(2-3): 217-224. http://dx.doi.org/10.1016/s0144-8617(98)00025-3

ROMAN, M. and WINTER, W. T. 2002. Nanocomposites of cellulose acetate butyrate reinforced with cellulose nanocrystals. Journal of Polymers and the Environment, 10(1-2), 27-30. http://dx.doi.org/10.1002/pts.2043.

ROMERO-BASTIDA, C. A., BLLO-PEREZ, L. A., GARCIA, M. A MARTINO, M. N., SOLORZA-FERIA, J. and ZARITZKY, N. E. 2005. Physicochemical and microstructural characterization of films prepared by thermal and cold gelatinization from non-conventional sources of starches. Carbohydrate Polymers, http://dx.doi.org/10.1016/j.carbpol.2005.01.004 60 , $235-244$

SAMIR, M. A. S. A., ALLOIN, F., SANCHEZ, J. Y. and DUFRENSE, A. 2004 Cellulose nanocrystals reinforced poly(oxyethylene). Polymer, 45(12), 41494157. http://dx.doi.org/10.1016/j.polymer.2004.03.094. 
SANTOS, P. V., SUZUKI, M. P., CEREDA, M. P. and SCAMPARINI, A. R. P. 2005. Microstructure and color of starch-gum films: Effects of gum deacetylation and additives. Part 2. Food Hydrocolloids, 19,1064-1073. http://dx.doi.org/10.1016/j.foodhyd.2005.02.007.

SAVADEKAR, N. R. and MHASKE, S. T. 2012. Synthesis of nano cellulose fibers and effect on thermoplastics starch based films. Carbohydrate Polymers, 89, 146-151. http://dx.doi.org/10.1016/j.carbpol.2012.02.063.

SEKER, M. and Hanna, M. A. 2006. Sodium hydroxide and trimetaphosphate levels affect properties of starch extrudates. Industrial Crops and Products, 23 249-255. http://dx.doi.org/10.1016/j.indcrop.2005.08.002 .

SIMKOVIC, I., HRICOVINI, M., MENDICHI, R. and SOEST, J. J. G. 2004 Cross-linking of starch with 1,2,3,4-diepoxybutane or 1,2,7,8-diepoxyoctane. Carbohydrate Polymers, 55 http://dx.doi.org/10.1016/j.carbpol.2003.10.002.

SOUZA LIMA, M. M. and BORASLI, R. 2004. Rod like cellulose microcrystals Structure, properties, and applications. Macromolecular Rapid Communications, 25(7), 771-787. http://dx.doi.org/10.1002/marc.200300268.

TIE, A. P. L., KARIM, A. A. and MANAN, D. M. A. 2008. Physicochemica properties of starch in sago palms (Metroxylon sagu) at different growth stages. Starch-Starke, 60, 408-416. http://dx.doi.org/10.1002/star.200700707.

THUWALL, M., BOLDIZAR, A. and RIGDAHL, M. 2006. Extrusion processing of high amylose potato starch materials. potato starch materials, 65(4), 441-446. http://dx.doi.org/10.1016/j.carbpol.2006.01.033.

THUNWALL, M., KUTHANOVA, V., BOLDIZAR, A. and RIGDAHL, M. 2008. Film blowing of thermoplastic starch. Carbohydrate Polymers, 71(4), 583590. http://dx.doi.org/10.1016/j.carbpol.2007.07.001

Torres, F. G., Troncoso, O. P., Torres, C., Díaz, D. A. and Amaya, E. 2011. Biodegradability and mechanical properties of starch films from Andean crops. International Journal of Biological Macromolecules, 48, 603-606. http://dx.doi.org/10.1016/j.ijbiomac.2011.01.026

TUHIN, M. O., RAHMAN, N., HAQUE, M. E., KHAN, R. A., DAFADER, N. C., ISLAM, R., NURNABI, M. and TONNY, W. 2012. Modification of mechanical and thermal property of chitosan-starch blend films. Radiation Physics and $\quad$ Chemistry, 1659-1668. http://dx.doi.org/10.1016/j.radphyschem.2012.04.015

VAN SOEST, J. J. G. and BORGER, D. B. 1997. Structure and properties of compression-molded Structure and properties of compression-molded. Journal of Applied Polymer Science, 64, 631-644. http://dx.doi.org/10.1002/(sici)10974628(19970425)64:4<631::aid-app2>3.0.co;2-o

VASCONEZ, M. B., FLORES, S. K., CAMPOS, C. A. ALVARADO, J. and GERSCHenson, L. N. 2009. Antimicrobial activity and physical properties of chitosan-tapioca starch based edible films and coatings. Food Research International, 42(7), 762-769. http://dx.doi.org/10.1016/j.foodres.2009.02.026.

VEIGA-SANTOS, P., OLIVEIRA, L. M., CEREDA, M. P., ALVES, A. J. and SCAMPARINI, A. R. P. 2005. Mechanical properties, hydrophilicity and wate activity of starch-gum films: effect of additives and deacetylated xanthan gum. Food Hydrocolloids, $\quad 19, \quad 341-349$. http://dx.doi.org/10.1016/j.foodhyd.2004.07.006

VEREGIN, R. P., FYFE, C. A., MARCHESSAULT, R. H. and TAYLOR, M. G 1986. Characterization of the crystalline A and B starch polymorphs and investigation of starchcrystallization by high-resolution carbon-13 CP/MAS NMR. $\quad$ Macromolecules, 19(4), 1030-1034 http://dx.doi.org/10.1021/ma00158a016.

VORWERG, W., DIJKSTERHUIS, J., BORGHIUS, J., RADOSTA, S. and KRO ER, A. 2004. Film Properties of Hydroxypropyl Starch. Starch - Stärke, 56(77), 297-306. http://dx.doi.org/10.1002/star.200300244.

WANG, L. Z. and WHITE, P. J.1994. Structure and Properties of Amylose, Amylopectin, and Intermediate Materials of Oat Starches. Cereal Chemistry, 71(3), 263-268.

WATTANACHANT, S.; MUHAMMAD, K. HASHIM, D, M.; RAHMAN, R. A. 2003. Effect of cross-linking reagents and hydroxypropylation levels on dualmodified sago starch properties. Food Chemistry, 80, 463-471. http://dx.doi.org/10.1016/s0308-8146(02)00314-x .

XU, Y. X., KIM, K. M., HANNAA, M. A. and NAG, D. 2005. Chitosan-starch composite film: Preparation and characterization. Industrial Crops and Products, 21(2), 185-192. http://dx.doi.org/10.1016/j.indcrop.2004.03.002

YANG, C. Q. and ANDREWS, B. A.K. Infrared spectroscopic studies of the nonformaldehyde durable press finishing of cotton fabrics by use of polycarboxylic. Journal of Applied Polymer Science, 43, 1609-1616. http://dx.doi.org/10.1002/app.1991.070430904

YU, J., WANG, N. and MA, X. 2005. The effects of citric acid on the properties of thermoplastic starch plasticized by glycerol. Starch - Starke, 57, 494-504. http://dx.doi.org/10.1002/star.200500423.

YOSHIMURA, M., TAKAYA, T. and NISHINARI, K. 1999. Effects of xyloglucan on the gelatinization and retrogradation of corn starch as studied by rheology and differential scanning calorimetry. Food Hydrocolloids, 13, 101-111. http://dx.doi.org/10.1016/s0268-005x(98)00075-7.

ZAMUDIO-FLORESamudio-FIORES, P. B., VARGAS-TORRES, A., PEREZ-

GONZALES, J., BOSQUEZ-MOLINA, E. and BELLO-PEREZ, L. A. 2006
Films Prepared with Oxidized Banana Starch: Mechanical and Barrier Properties. Starch - Stärke, 58, 274-282. http://dx.doi.org/10.1002/star.200500474.

ZAVAREZE, E. D. R., PINTO, B. K., KLEIN, B., Halal, S. L. M. E., Elias, M. C., Prentice-Hernández, C. and Dias, A. R. G. 2012. Development of oxidised and heat-moisture treated potato starch film. Food Chemistry, 132, 344-350. http://dx.doi.org/10.1016/j.foodchem.2011.10.090.

ZHANG, J., ELDER, T. J., PU, Y. and RAGAUSKAS, A. J. 2007. Facile synthesis of spherical cellulose nanoparticles. Carbohydrate Polymers, 69(3), 607-611. http://dx.doi.org/10.1016/j.carbpol.2007.01.019.

ZHONG, Y., SONG, X. and LI, Y. 2011. Antimicrobial, physical and mechanical properties of kudzu starch-chitosan composite films as a function of acid solvent types. Carbohydrate Polymers, 84: 335-342. http://dx.doi.org/10.1016/j.carbpol.2010.11.041.

ZOBEL, H. F. Molecules to Granules: A Comprehensive Starch Review. Starch Stärke, 40(2), 44-50. http://dx.doi.org/10.1002/star.19880400203. 